\section{Toward a Reflexive Internationalization}

\section{Prema refleksivnoj \\ internacionalizaciji}

\author{
Mirko PETRIĆ \\ Odjel za sociologiju, Sveučilište u Zadru / \\ Department of Sociology, University of Zadar, Croatia \\ mpetric@unizd.hr
}

What first came to my mind following the reading of Valerio Baćak's recent Forum contribution (Baćak, 2011) was the well known sceptical argument put forth by the Sophist Gorgias. Sketchily retold for illustrative purposes, this argument suggests that even if we were able to understand something and to communicate it to others, they would not understand what we were saying.

After having re-read Baćak's contribution, I am almost convinced that what I am writing now will again be misconstrued or rejected as impertinent by my interlocutor. To be sure, the reverse is true as well: my interlocutor could say the same about my perception of his arguments.

Why bother to write, then? The answer is simple: because our dialogue is also followed by other readers, who may draw their own conclusions after reading our exchanges. In this context, I would like my positions to be understood as I intended them and not as they were (mis) represented by my interlocutor.

Therefore, I will first try in what follows to restate the aim of and explain the motivation for my previous Forum contribution (Petrić, 2011). Following
Prvo što mi je palo na um nakon čitanja nedavnog priloga Valerija Baćka u Forumu (Baćak, 2011) bio je skeptički argument sofista Gorgije. Prepričan ukratko u puko ilustrativnu svrhu, taj argument sugerira da čak i kad bismo bili u stanju nešto razumjeti i to prenijeti drugima, oni ne bi razumjeli što im govorimo.

Nakon što sam ponovo pročitao Baćkov prilog, gotovo sam uvjeren da će ovo što sada pišem moj sugovornik ponovo pogrešno razumjeti ili odbaciti kao nevažno. Istini za volju, vrijedi i obratno: moj bi sugovornik mogao reći isto o mojoj percepciji njegovih argumenata.

Zašto onda uopće pisati? Odgovor je jednostavan: stoga što naš dijalog prate i drugi čitatelji/ce, koji nakon čitanja naših razmjena misli mogu doći do vlastitih zaključaka. S obzirom na to, želio bih da se moji stavovi i pogledi razumiju onako kako sam ih namjeravao posredovati, a ne onako kako ih je (pogrešno) predstavio moj sugovornik.

U nastavku ću stoga najprije pokušati ponovo prikazati svrhu i objasniti motive nastanka svoga prethodnog priloga u Forumu (Petrić, 2011). Potom ću pokušati prikazati neka od izobličenja 
that, I will try to illustrate some of the distortions that my arguments were subjected to in my interlocutor's reports on them. Finally, I will take up the subject my interlocutor chose to concentrate on ("internationalization"), briefly discuss some of its aspects connected with the dominance of "bibliometric imagination", and - by way of conclusion - present my general position on it.

Bibliometrics or internationalization? To be able to continue this discussion, one should first establish what it is focused on. In other words, are we - in the first instance - speaking about bibliometrics or about internationalization? There is no doubt that these are related subjects, but for analytical purposes it would be useful to view them separately at this stage.

I trust that the main thrust of my Forum contribution was succinctly summarized by its title: "Bibliometrics cum grano". It is reasonable to expect that most readers would understand the overall message of the text bearing the quoted title as follows: the results of bibliometric exercises should not be taken at face value.

This was, indeed, the focal point around which the content of my whole text was developed. My aim was to turn the attention of the readers of the Štulhofer, Baćak and Šuljok (2010) Forum contribution, as well as of its authors, to the fact that - in the field of sociology - there exist good reasons to be sceptical of the validity of the natural sciences-style approach to quantified evaluations of academic research.

What I had to say about the perils of what Hanafi (2010) labels as "simple internationalization" is also closely related to bibliometric issues. Namely, the pro- kojima su moji argumenti bili izloženi u izvješćima moga sugovornika. $\mathrm{Na}$ koncu, pozabavit ću se i sam temom na koju se moj sugovornik odlučio usredotočiti (»internacionalizacija«), ukratko raspraviti neke njezine aspekte povezane sa sve većom prevlašću »bibliometrijske imaginacije« i potom u zaključku predočiti svoj načelni stav o njoj.

Bibliometrija ili internacionalizacija? Da bi se rasprava mogla nastaviti, valjalo bi međutim najprije utvrditi što joj je žarište. Drugim riječima, govorimo li - u prvom redu - o bibliometriji ili o internacionalizaciji? Nema sumnje da su ove teme povezane, ali na ovom bi ih stupnju rasprave bilo korisno odvojeno promatrati $\mathrm{u}$ analitičke svrhe.

Vjerujem da je glavno težište mog priloga bilo primjereno izraženo samim njegovim naslovom: »Bibliometrija cum grano«. Čini mi se razumnim očekivati da bi većina čitatelja/ica mogla razumjeti ukupnu poruku teksta s takvim naslovom na sljedeći način: rezultate bibliometrijskih provjera ne bi trebalo uzimati zdravo za gotovo.

Ovo doista i jest žarište oko kojega se razvio sadržaj čitavoga moga teksta. Namjera mi je bila skrenuti pozornost čitatelja i čitateljica priloga u Forumu Štulhofera, Baćka i Šuljok (2010), a isto tako i njegovih autora $\mathrm{i}$ autorice, na činjenicu da - na području sociologije postoje dobri razlozi za skepsu u pogle$\mathrm{du}$ validnosti kvantificiranih evaluacija znanstvenih istraživanja uobičajenih $\mathrm{u}$ prirodnim znanostima.

Ono što sam želio reći o opasnostima »jednostavne internacionalizacije« kako je naziva Hanafi (2010) - također je blisko povezano s bibliometrijskim temama. Naime, proces koji se može općenito opisati ovom oznakom uvelike 
cess that can be generally described by this label is largely based on the attempts to achieve institutional isomorphism with the "global players" by means of increased participation in "international knowledge production”. Apart from sharing an unshaken modernist belief in the "objectivity" of knowledge and the easily established hierarchies of its importance, the proponents of this approach also tend to believe in the objectivity and undisputable relevance of any set of quantitatively assessed data.

This is where bibliometric issues meet the subject-matter of "internationalization". However, I would not perhaps have made the connection explicit and devoted "a substantial part of [my] comments" to "a speculation about the possible negative consequences of the effort to internationalize" (Baćak, 2011: 239), had the authors of the text that served as the initial impetus for our dialogue (Štulhofer, Baćak and Šuljok, 2010) not explicitly invoked Inga Tomić-Koludrović's presidential address given at the 2009 congress of the Croatian Sociological Association (Tomić-Koludrović, 2009).

"Multiparadigmatic”, "reflexive”, "public"? To make a potentially very long story short, let me just say here that I took Tomić-Koludrović's invitation to internationalize to be additionally qualified by the elements of her vision of Croatian sociology as "multiparadigmatic", "reflexive" and "public". My message was (or was to be) that a narrowly conceived evaluation of academic research, based predominantly on bibliometric criteria, should be viewed as potentially damaging precisely to those aspects of sociological activity singled out by Tomić-Koludrović as crucial in the attempts to overcome the "insufficient se zasniva na pokušajima postizanja institucionalne izomorfnosti s $» g l o b a l n i m$ igračima« na temelju povećanog sudjelovanja $\mathrm{u}$ »međunarodnoj proizvodnji znanja«. Osim što dijele nepoljuljano modernističko uvjerenje u »objektivnost« znanja i laku uspostavu hijerarhija njegove važnosti, zagovaratelji ovog pristupa također su skloni vjerovati $\mathrm{u}$ objektivnost i neupitnu relevantnost bilo kojega niza kvantitativno evaluiranih podataka.

$\mathrm{Na}$ ovom se mjestu bibliometrijske teme susreću s tematikom »internacionalizacije«. No, njihovu vezu možda ne bih bio učinio eksplicitnom i posvetio "znatan dio [svog] komentara [...] spekulacijama o mogućim negativnim posljedicama zalaganja za internacionalizaciju« (Baćak, 2011: 239), da se autori i autorica teksta koji je poslužio kao početni poticaj našem dijalogu (Štulhofer, Baćak i Šuljok, 2010) nisu eksplicite pozvali na predsjednički govor Inge Tomić-Koludrović, održan na kongresu Hrvatskoga sociološkog društva 2009. godine (Tomić-Koludrović, 2009).

»Multiparadigmatska«, »refleksivna«, »javna«? Da bih skratio potencijalno vrlo dugu priču, ovdje ću reći tek to da sam poziv Inge Tomić-Koludrović na internacionalizaciju razumio kao dodatno kvalificiran elementima njezine vizije hrvatske sociologije kao »multiparadigmatske«, »refleksivne« i »javne«. Moja je poruka bila (ili je trebala biti) da bi usko shvaćenu evaluaciju znanstvenih istraživanja, uglavnom zasnovanu na bibliometrijskim kriterijima, valjalo smatrati potencijalno štetnom upravo po one aspekte sociološke djelatnosti koje je Tomić-Koludrović izdvojila kao ključne pri pokušajima prevladavanja »nedovoljne teorijske i metodologijske spremnosti hrvatske 
theoretical and methodological capability [of Croatian sociology] to respond to the complex processes Croatian society is faced with in the post-socialist period" (Tomić-Koludrović, 2009: 139).

Admittedly, I have failed to expound at length on how the regime of knowledge production, steered by allegedly "objectivist" quantitative assessment, clashes with and hinders the development of Tomić-Koludrović's de-

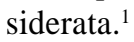

Instead, due largely to limitations of space, I have simply situated the discussion into a context outlined by well known concepts from Giddens's, Bauman's and Burawoy's work. Following that, I have reported on the central dilemma "faced by the sociologists from the societies and cultures whose 'local'

${ }^{1}$ To avoid any misunderstanding, this time I would like to state explicitly what I merely hinted at discursively by reporting on Hanafi's positioning of the problem in my previous Forum contribution (Hanafi, 2010, 2011). In order to become truly "multiparadigmatic" in the way envisioned by TomićKoludrović, Croatian sociology would among other things - need a significant increase in the number of qualitative field research efforts. Uncritical and unreflected acceptance of a regime of knowledge production described by Hanafi as privileging theoretical and statistical analysis to the detriment of fieldwork certainly cannot be viewed as contributing to improvements in this regard. Likewise, the linear nature and objectivist imperatives of what Hanafi labels as "simple internationalization" are certainly not conducive to more reflexivity desired by Tomić-Koludrović. Finally, the lack of ample space in international journals for sociological responses to situated "local" questions, reported on by Hanafi, is at odds with the mission of public sociology advocated by Tomić-Koludrović. sociologije da odgovori na kompleksne procese s kojima se hrvatsko društvo suočava u postsocijalističkom razdoblju« (Tomić-Koludrović, 2009: 139).

Valja priznati da sam propustio naširoko razglabati o tome kako se režim proizvodnje znanja koji usmjerava navodno »objektivistička« kvantitativna procjena sukobljava s ishodima koje priželjkuje Tomić-Koludrović i kako točno ometa njihov razvoj. ${ }^{1}$

Umjesto toga, uglavnom zbog ograničenosti prostora, jednostavno sam situirao raspravu u kontekst ocrtan konceptima dobro poznatim iz Giddensova, Baumanova i Burawoyeva rada. Nakon toga, izvijestio sam o središnjoj dvojbi »pred kojom se [...] nalaze sociolozi/ ginje iz društava i kultura čiji 'lokalni' problemi istodobno nisu i 'globalni'«

${ }^{1}$ Da bi se izbjegli nesporazumi, ovaj put želio bih eksplicite iznijeti ono što sam u svom prethodnom prilogu u Forumu tek diskurzivno naznačio prenošenjem Hanafijeva postavljanja problema (Hanafi, 2010, 2011). Da bi postala doista »multiparadigmatska« na način koji zamišlja TomićKoludrović, hrvatskoj sociologiji potreban je - između ostaloga - značajan porast broja kvalitativnih terenskih istraživanja. Nekritičko i nereflektirano prihvaćanje režima proizvodnje znanja koji - kako iznosi Hanafi - privilegira teorijsku i statističku analizu nauštrb terenskog rada zasigurno se ne može vidjeti kao doprinos boljitku $\mathrm{u}$ ovom pogledu. $\mathrm{Na}$ isti način, linearna priroda i objektivistički imperativi onoga što Hanafi naziva $» j$ jednostavnom internacionalizacijom« zasigurno ne vode većoj refleksivnosti, koju priželjkuje Tomić-Koludrović. Konačno, nedostatak prostora u međunarodnim časopisima za sociološke odgovore na situirana »lokalna« pitanja o kojem izvješćuje Hanafi - očito nije u skladu s poslanjem javne sociologije, koju zagovara Tomić-Koludrović. 
problems are not considered to be 'global' at the same time" (Petrić, 2011: 109$110)$, as it is represented in the work of a prominent and engaged analyst of such a situation (Sari Hanafi). Finally, I have proposed an approach to internationalization that I thought could help avoid some of the traps brought about by what could - for brevity's sake - be described as impact factor-directed research.

Unfounded fears? I confess that I fail to understand why all of this was perceived by my interlocutor as reducible to an expression of "unfounded fears of academic imperialism" and connected with the "fear that we will harm Croatian sociology or Croatian society by insisting on internationalization" (Baćak, 2011: 244).

True enough, given the limitations of space and the very nature of the contribution, I did not have a chance to quote at length from a sizeable body of literature suggesting that fears of academic imperialism are by no means "unfounded”. Nevertheless, I believed that the general positioning of the discussion and the arguments I reported on or developed in the final part of my text would be sufficient for a benevolent reader to understand what my position on the perils of "simple internationalization" was. My interlocutor's recent response clearly shows that this belief was erroneous.

Who is tendentious after all? My interlocutor devoted the bulk of his discussion to the "problems" arising with the "implications drawn from [my] critical contextualization” (Baćak, 2011: 239 /italics mine/) of the bibliometric analysis carried out by Štulhofer, himself and Šuljok. In literally one sentence that he devotes to my contextualization itself, he character-
(Petrić, 2011: 109-110), onako kao što je ona prikazana u radovima prominentnog i angažiranog analitičara takvog stanja (Sari Hanafi). Konačno, predložio sam pristup internacionalizaciji za koji mislim da bi mogao pomoći u izbjegavanju nekih zamki koje donosi ono što bi se - kratkoće radi - moglo opisati kao znanstvena istraživanja vođena ponajprije željom za postizanjem što većeg čimbenika utjecaja (impact factor).

Neutemeljeni strahovi? Priznajem da ne uspijevam shvatiti kako je moj sugovornik percipirao sve ovo kao nešto što se može svesti tek na izraz »neutemeljeni[h] strahov[a] od akademskog imperijalizma« i povezati s »bojaz[ni] da inzistiranjem na internacionalizaciji možemo naštetiti hrvatskoj sociologiji ili hrvatskom društvu« (Baćak, 2011: 244).

Istina, s obzirom na ograničen prostor i samu narav priloga, nisam imao prilike naširoko navoditi iz pozamašnog korpusa literature koja sugerira da strahovi od akademskog imperijalizma uopće nisu »neutemeljeni«. Bez obzira na to, bio sam uvjeren da su općenita postavljenost rasprave i argumenti o kojima sam izvijestio ili sam ih sâm iznio u završnom dijelu svog teksta dovoljni da benevolentan čitatelj ili čitateljica shvate kakav je moj odnos prema opasnostima »jednostavne internacionalizacije«. Nedavni odgovor mog sugovornika jasno pokazuje da je ovo uvjerenje bilo pogrešno.

Tko je naposljetku tendenciozan? Moj sugovornik posvetio je najveći dio svoje rasprave »problematičn[im] implikacija[ma] do kojih Petrić dolazi na osnovi [svoje] kritičke kontekstualizacije« (Baćak, 2011: 239 /kurziv moj/) bibliometrijske analize što su je obavili Štulhofer, on sâm i Šuljok. U doslovno jednoj rečenici koju posvećuje 
izes it as "thorough, although tendentious" (Baćak, 2011: 239).

The question, however, is whose analysis deserves to be labelled as "tendentious": that of the team my interlocutor participated in or mine? I leave the decision on this to the good judgment of the readers. Nevertheless, I would like to remark in passing that an analysis containing a part in which internationally referenced research results of solely senior scientists employed in one sociology department of a Croatian university are contrasted with the results of senior scientists employed in two (?) departments of a Slovenian university, and then with the results of the scientists operating in a bibliometrically incomparable field (psychology), cannot really be considered to be completely free of "tendentiousness". The same goes for the decision to exclude from the analysis research results published in "local" journals, even if they are referred in relevant international databases.

Whose "methodological nationalism"? Following the comment of my interlocutor's perception of the tendentiousness of my text, I would also like to say that I do not think it is fair that only my "emphasis placed on the local social problems" (Baćak, 2011: 241) should be judged as "partly reflect[ing]" what has been described in recent sociological discussions as "methodological nationalism”.

If we are to refer to "the territorialization of social science imaginary and the reduction of the analytical focus to the boundaries of the nation-state" (Wimmer and Glick Schiller, 2002: 307), one should bear in mind that it was actually the title of the Štulhofer, Baćak and Šuljok (2010) Forum contribution ("A samoj mojoj kontekstualizaciji, opisuje ju kao »podrobn[u]), iako na trenutke tendenciozn[u])« (Baćak, 2011: 239).

Pitanje je, međutim, čija analiza zaslužuje etiketu »tendenciozne«: ona tima u kojem je sudjelovao moj sugovornik ili moja? Odluku o tome ostavljam prosudbi čitatelja/ica. Svejedno, želio bih ipak usput spomenuti da analiza koja sadržava dio u kojem se međunarodno referirani znanstveni rezultati samo znanstvenika u najvišim zvanjima zaposlenim na jednom odsjeku jednoga hrvatskog sveučilišta uspoređuju s rezultatima znanstvenika u najvišim zvanjima zaposlenim na dvama (?) odsjecima jednoga slovenskog sveučilišta, a potom s rezultatima znanstvenika koji djeluju $\mathrm{u}$ bibliometrijski neusporedivom polju (psihologije), ne mogu smatrati potpuno lišenim »tendencioznosti«. Isto vrijedi $\mathrm{i}$ za odluku da se u analizi izostave rezultati istraživanja objavljivani u »lokalnim« časopisima, čak i kad su ti časopisi referirani u međunarodno relevantnim bazama podataka.

Čiji »metodološki nacionalizam«? Nakon komentara sugovornikove percepcije o tendencioznosti mog teksta, želio bih reći da ne mislim da je pravedno da samo za moj »naglas[ak] [...] na lokalne društvene probleme« (Baćak, 2011: 241) bude konstatirano da »djelomično izražava« ono što se u nedavnim sociološkim raspravama naziva »metodološkim nacionalizmom«.

Govori li se o »teritorijalizacij[i] imaginarija društvene znanosti i suža$\operatorname{vanj}[\mathrm{u}]$ njezinog analitičkog fokusa $\mathrm{u}$ granice nacionalne države« (Wimmer i Glick Schiller, 2002: 307), valjalo bi imati na umu da je zapravo naslov priloga u Forumu Štulhofera, Baćka i Šuljok (2010) (»Provincijalni karakter hrvatske 
Parochial Status of Croatian Sociology?") that introduced the national "container" as a seemingly logical frame of reference to which I simply responded in my text.

To make things worse, judged by the yardstick introduced by my interlocutor, the authors of the bibliometric analysis that set our dialogue in motion could actually be accused of a "double" methodological nationalist perspective: their analytical focus can be seen as actually delimited by the boundaries of two nation-states (Croatia and former Yugoslavia).

After all, in contrast with Štulhofer, Baćak and Šuljok (2010), I established a link between what I saw as an emerging "local" Croatian problem with a description of a comparable situation in several countries of the Arab East (Egypt, Syria, the Palestinian territory, Jordan, and Lebanon). This would seem to me to be more "internationalized" and "global" (i.e. less "methodologically nationalistic") than referring to the situation in the neighbouring country that until relatively recently - and in any case still within living memory - was a part of the same national "container".

More tendentiousness? Returning now to the previously mentioned exclusion of internationally referred "local" journals from the bibliometric analysis performed by Štulhofer, Baćak and Šljok, as well as to their decision to compare the results of a chosen group of sociologists from Croatia only with their counterparts from Slovenia, one is tempted to view both almost as a sort of a combination of "tendentiousness" and "methodological nationalism".

What is "tendentious" or simply "unfair" about these decisions is that they were obviously made in order to substan- sociologije?«) uveo nacionalni »spremnik« kao naizgled logičan referentni okvir na koji sam jednostavno odgovorio u svom tekstu.

Da stvari budu još gore - mjere li se mjerilima koja je uveo moj sugovornik - autore i autoricu bibliometrijske analize koja je pokrenula naš dijalog moglo bi se zapravo optužiti za »dvostruku« metodološkonacionalističku perspektivu: žarište njihove analize može se vidjeti kao omeđeno granicama dviju nacionalnih država (Hrvatske i bivše Jugoslavije).

Nakon svega, za razliku od Štulhofera, Baćka i Šuljok (2010), ja sam doveo u vezu ono što sam smatrao sve nazočnijim »lokalnim« hrvatskim problemom s opisom usporedivog stanja u nekoliko zemalja arapskog Istoka (Egiptu, Siriji, Palestinskim teritorijima, Jordanu i Libanonu). To mi se čini »internacionaliziranijim« $\mathrm{i}$ »globalnijim« ( $\mathrm{tj}$. manje »metodološki nacionalističkim«) od referiranja na stanje u susjednoj zemlji koja je razmjerno donedavno (a u svakom slučaju još u živom sjećanju) bila dio istoga nacionalnog »spremnika«.

Još tendencioznosti? Vratimo li se sad prethodno spomenutom isključenju međunarodno referiranih »lokalnih« časopisa iz bibliometrijske analize koju su obavili Štulhofer, Baćak i Šuljok, kao i njihovoj odluci da usporede rezultate odabrane skupine sociologa iz Hrvatske samo s onima njihovih kolega iz Slovenije, pada se u iskušenje vidjeti i jednu i drugu odluku gotovo kao neku vrstu kombinacije »tendencioznosti« $\mathrm{i} » m e t o-$ dološkog nacionalizma«.

U ovim odlukama »tendenciozno« je ili jednostavno »nepravedno « to što su očito donesene da bi se dodatno pot- 
tiate further the desired conclusion (i.e. to emphasize that the presence of Croatian sociologists in international peer-reviewed journals is low). "Methodological nationalism" enters into the discussion when one realizes that this simple (and undisputed) fact acquires somewhat more dramatic overtones in comparison with a closely related - but more successful member of the former common national "container" (Slovenia).

Had the authors chosen any other part of the former Yugoslav national container - with the partial exception of Serbia - as a basis for their comparison, the international visibility of Croatian sociology would have actually seemed to be rather impressive. Even more, in such a context Croatia would have appeared as a small wonder of sociological internationalization.

Incidentally, this is exactly what my interlocutor thinks - without any grounding - that I said in my contextualization of Štulhofer's, his and Šuljok's analysis (!?).

Who said what? It is indeed hard to understand on the basis of what one could conclude that in my Forum contribution I "stress, without qualification (or providing a context) that we are actually a third sociological force in Europe" (Baćak, 2011: 240). It is even more odd that it is my interlocutor who, following the quoted excerpt, attempts to relativize what he thinks is the bibliometric foundation for my alleged statement ("Christian Fleck's [...] bibliometric analysis", as he sees it and refers to it). He does this by saying that Fleck's analysis also takes into account "Croatian journals [...] which were not included in our analysis because publishing in local journals, even if they are referred in relevant databases, tells little about global scientific presence" (Baćak, 2011: 240). krijepio željeni zaključak (tj. da bi se dodatno naglasilo da je nazočnost hrvatskih sociologa u međunarodno recenziranim časopisima mala). »Metodološki nacionalizam« pak ulazi u raspravu kad se shvati da ova jednostavna (i neosporavana) činjenica poprima nešto dramatičnije tonove u usporedbi s bliskom - ali uspješnijom - članicom nekad zajedničkoga bivšega nacionalnog »spremnika« (Slovenijom).

Da su autori i autorica svoju usporedbu temeljili na bilo kojem drugom dijelu bivše Jugoslavije - s djelomičnom iznimkom Srbije - međunarodna vidljivost hrvatske sociologije činila bi se zapravo prilično dojmljivom. Štoviše, u tom kontekstu, Hrvatska bi se činila pravim malim čudom sociološke internacionalizacije.

Usput rečeno, moj sugovornik bez ikakve osnove - misli da je upravo to ono što sam ja rekao u svojoj kontekstualizaciji analize koju su obavili Štulhofer, on i Šuljok (!?).

Tko je rekao što? Doista je teško razumjeti na kojoj je osnovi bilo tko mogao zaključiti da je u mom prilogu u Forumu »bez kvalificiranja (ili kontekstualizacije) bilo izdvojeno kako smo zapravo treća sociološka sila u Europi« (Baćak, 2011: 240). Još je čudnije što baš moj sugovornik, nakon navedenog ulomka, pokušava relativizirati ono što misli da je bibliometrijska osnova moje navodne tvrdnje (»bibliometrijsk[a] analiz[a] Christiana Flecka«, kako je naziva). Čini to govoreći da Fleckova analiza uzima u obzir $»$ i hrvatsk[e] časopis[e], koje smo izostavili iz naše analize jer objavljivanje u lokalnim časopisima, makar referiranim u relevantnim bazama, govori malo o globalnoj znanstvenoj prisutnosti« (Baćak, 2011: 240). 
To begin with, one should say that it is a fine twist of irony that Fleck's analysis, by virtue of its very existence, actually contradicts the statement quoted above. Articles published in Croatian journals and referenced in the Social Sciences Citation Index (SSCI) were obviously indiscriminately taken into account in an analysis performed by a serious scholar, presented at an international conference and published in conference proceedings sponsored by the Council of National Associations of the International Sociological Association. In other words, articles published in "local journals" - by virtue of their presence in what my interlocutor would no doubt consider to be a "relevant" database - have in this case obviously achieved a sort of (collective) global scientific presence. ${ }^{2}$

But this is not the issue at point. More worrying indeed - to return to our dialogue - is that my interlocutor seems to fail to understand why I have chosen to quote from Fleck's text (Fleck, 2010) in the first place and what this text is actually about.

${ }^{2}$ I hasten to add that I understand very well that "presence" is different from "impact", but also that it was not I who used the word "presence" in this case but my interlocutor. I quote his explanation of the rationale behind the Štulhofer, his and Šuljok analysis: "We wanted to examine whether senior Croatian sociologists are present in international peer-reviewed journals that are available to potential readership worldwide through the relevant and relatively selective bibliographic databases" (Baćak, 2011: 240). To that end, as my interlocutor also explicitly stated, the importance of the impact factor has been completely disregarded: "we have included in the analysis many journals that did not even have an impact factor" (Baćak, 2011: 240).
Za početak, valjalo bi reći da je doista ironično to što Fleckova analiza već i samim svojim postojanjem demantira gore navedenu tvrdnju. Članke objavljene u hrvatskim časopisima i referirane u Social Sciences Citation Index (SSCI) u svojoj je analizi očito uzeo u obzir ozbiljan znanstvenik, koji je tu analizu prezentirao na međunarodnoj konferenciji i objavio u zborniku skupa pod pokroviteljstvom Savjeta nacionalnih društava Međunarodnoga sociološkog društva. Drugim riječima, članci objavljeni u »lokalnim časopisima« - zahvaljujući svojoj nazočnosti u bazi podataka koju bi moj sugovornik nesumnjivo smatrao »relevantnom《 u ovom su slučaju očito postigli neku vrstu (kolektivne) globalne znanstvene prisutnosti. $^{2}$

No, to nije ono o čemu govorimo u ovom dijelu teksta. Znatno više zabrinjava - vratimo se našem dijalogu - što moj sugovornik čini se ne razumije zašto sam uopće odabrao citirati Fleckov tekst (Fleck, 2010), kao ni to o čemu je $\mathrm{u}$ tom tekstu zapravo riječ.

2 Želio bih smjesta dodati da vrlo dobro razumijem razliku između "prisutnosti« $\mathrm{i}$ »utjecaja«, ali također i to da u ovom slučaju nisam ja upotrijebio riječ »prisutnost«, nego moj sugovornik. Navodim njegovo objašnjenje svrhe analize koju su obavili Štulhofer, on i Šuljok: »htjeli [smo] istražiti jesu li etablirani hrvatski sociolozi prisutni $\mathrm{u}$ recenziranim međunarodnim časopisima koji su, putem relevantnih i razmjerno selektivnih referentnih baza, dostupni zainteresiranim čitateljima diljem svijeta« (Baćak, 2011: 240). U tu svrhu - što je također eksplicite izjavio moj sugovornik - važnost čimbenika utjecaja bila je potpuno zanemarena: »u našu smo analizu uključili i mnoge časopise koji čimbenik utjecaja nisu niti imali« (Baćak, 2011: 240). 
What is more, one could even suspect that he has not even read my text very closely, since I provided a report in it about Fleck questioning the validity of SSCI. Likewise, I have extensively quoted from other Fleck statements on the topic and provided reports about the examples that have led him to the conclusion that sociology remains a discipline bounded by the nation-state or language borders, within which comparisons of impacts beyond the borders of particular national or specialized disciplinary discourse communities do not make much sense.

In other words, I have more than aptly "qualified" and "contextualized" the quoted piece of information, according to which Croatian sociology ranked third in Europe based on the number of articles indexed in SSCI in the period between 1990 and 2008, in relation to the number of inhabitants. I have done so by quoting a reliable source suggesting that bibliometrical comparisons similar to the one upon which the quoted piece of information was based do not make much sense! ${ }^{3}$

${ }^{3}$ Fleck's thorough and stimulating analysis is certainly not the only source that could have been quoted to substantiate the contextualization I have suggested. If an authoritative institutional seconding of Fleck's conclusions is needed, one could turn to the recent report by the French Academy of Sciences stating that databases "cannot pertinently reflect the scientific activity in SHS" (i.e. in the "social and human sciences"), as well as that "Thomson Reuters managers confirm this observation" (Académie des sciences, 2011: 47). It is interesting to note that this report reaches the same conclusion as another individual researcher I have quoted in my Forum contribution (Jacobs, 2011), in that it states that in SHS - in contrast with other fields of science - "[t]here is a higher cita-
Štoviše, moglo bi se posumnjati da nije odviše pomno proučio čak ni moj tekst, jer sam u njemu izvijestio o Fleckovu dovođenju u pitanje validnosti SSCI-ja. Isto tako, opsežno sam navodio druge Fleckove tvrdnje o temi, te izvijestio o primjerima koji su ga naveli na zaključak da sociologija ostaje disciplinom omeđenom nacionalnim ili jezičnim granicama, u kojoj usporedbe utjecaja nemaju odviše smisla ponad tih granica ili granica pojedine disciplinarne zajednice diskursa.

Drugim riječima, navedeni podatak o trećem mjestu hrvatske sociologije u Europi po broju članaka referiranih u SSCI-ju između 1990. i 2008. u odnosu na broj stanovnika, više sam nego primjereno »kvalificirao« $\mathrm{i} » k \mathrm{kon}-$ tekstualizirao« navođenjem pouzdanog izvora koji ukazuje na to da bibliometrijske usporedbe poput one na kojoj se taj podatak zasniva nemaju odviše smisla! ${ }^{3}$

3 Fleckova temeljita i poticajna analiza zasigurno nije jedini izvor koji se mogao navesti u potporu predložene kontekstualizacije. Ako je potrebna autoritativna institucionalna potvrda Fleckovih zaključaka, moglo bi ju se naći u nedavnom izvješću francuske Akademije znanosti, u kojem se tvrdi da baze podataka »ne mogu pertinentno odraziti znanstvenu aktivnost $u$ SHS « (tj. u »društvenim i humanističkim znanostima «), kao i to da »voditelji Thomson Reutersa potvrđuju ovo zapažanje« (Académie des sciences, 2011: 47). Zanimljivo je primijetiti da ovo izvješće dolazi do istih zaključaka kao i drugi individualni istraživač (Jacobs, 2011) kojega sam citirao u svom prilogu u Forumu, utoliko što se u njemu tvrdi da u društvenim i humanističkim znanostima "postoji veća citatna frekventnost za starije članke (prije 2000. i čak 
On the basis of his obviously not understanding this, one is forced to conclude that discursive arguments and indirect references do not fare well with my interlocutor. ${ }^{4}$ This is again shown by his obviously not understanding that it was not "Petrić" who put forth all the "unfounded”, “arbitrary”, "unaccounted" claims about "academic imperialism" and "mechanisms of exclusion of certain topics and approaches from international journal production".

Due to its nature, my text could offer no more than cursory glimpses into an extensive ongoing debate, which I nevertheless thought were necessary to complement what has been referred to as "a bibliometrically limited view of a complex reality" (Van Raan, 2005: 134). But even if a wider context was not amply presented, it should have been clear

tion frequency for older articles (pre-2000 and even pre-1980)" (Académie des sciences, 2011: 47). Finally, it should not go unnoticed that the results of the Bibliometrics pilot exercise sponsored by the Higher Education Funding Council for England (HEFCE) suggested that citation information (in general) is "not sufficiently robust to be used formulaically as a primary indicator of quality" (HEFCE, 2010).

${ }^{4}$ Apart from failing to grasp the indirect "contextualization" by means of quoting the arguments of other researchers, my interlocutor has also failed to take into account a number of signals in my text relativizing the controversial piece of information even before it was put forth. These include the modal auxiliary "could" (expressing "possibility in contingent circumstances"), adverbs "perhaps" and "seemingly" (indicating "a lack of certainty" and "in appearance but not necessarily in actuality"), as well as distancing phrases "at a most superficial level" and "intentionally [...] within the limits".
S obzirom na to da ovo očito nije razumio, ne može se nego zaključiti da diskurzivni argumenti i neizravne reference kod mog sugovornika ne prolaze dobro. ${ }^{4}$ Ovo se ponovo pokazuje njegovim očitim nerazumijevanjem da nije »Petrić« iznio sve »neutemeljene«, »proizvoljne«, »neobrazložene« teze o »akademskom imperijalizmu« i »mehanizmima isključivanja pojedinih tema i pristupa iz međunarodne časopisne produkcije«.

Već zbog svoje prirode, moj tekst nije mogao ponuditi više od letimičnih uvida u opsežnu aktualnu raspravu. Smatrao sam, ipak, da su i takvi brzi pogledi bili nužni kao dopuna »bibliometrijski ograničenom pogledu na kompleksnu zbilju« (Van Raan, 2005: 134). No, čak i ako širi kontekst nije bio opsežno predočen, iz moga je teksta tre-

prije 1980.)« (Académie des sciences, 2011: 47) nego što je to slučaj u drugim područjima znanosti. Konačno, ne bi trebalo proći nezamijećeno da rezultati Bibliometrijskog pilot-istraživanja pod pokroviteljstvom Savjeta za financiranje visokog školstva u Engleskoj (HEFCE) pokazuju da informacije o citiranosti (općenito) »nisu dovoljno robusne da bi ih se formulaično koristilo kao primaran indikator kvalitete« (HEFCE, 2010).

${ }^{4}$ Osim što nije uspio shvatiti neizravnu »kontekstualizaciju« obavljenu navođenjem argumenata drugih istraživača, moj sugovornik također nije uzeo u obzir više signala u mom tekstu koji su relativizirali sporni podatak čak i prije nego što je bio iznesen. Riječ je o kondicionalnoj konstrukciji izgrađenoj oko glagolskog pridjeva radnog »moglo« (što podrazumijeva više mogućih ishoda), prilozima »možda« (izražava nedostatak izvjesnosti) i »naizgled« (odnosno »u izgledu ali ne nužno i stvarno«), kao i frazama distanciranja »na najpovršnijoj razini« i »namjerno [...] unutar granica $\ll$. 
from my text that it was not I who put forth all these arguments, just as it was Hanafi and not I who came up with the rhetorically graphical expression of the dilemma facing academic sociologists in the Arab East ("publish globally and perish locally" or "publish locally and perish globally").

Ignorance does not excuse. Obvious ignorance of the content and tenets of numerous well-informed contributions to a wide-ranging intellectual debate some of which also include empirical data of expressly bibliometric nature does not really excuse my interlocutor's easy dismissal of my preoccupation with not compromising one's research mission and not bypassing the needs of the local community when trying to meet the success criteria of an ever more globalized research system.

Where he reduces this preoccupation to "an unfounded fear of publishing in international journals" (Baćak, 2011: 241), more experienced and knowledgeable participants in the debate mentioned above offer a wealth of arguments and examples to the contrary. Since my argumentative skills have obviously failed to drive this home to my interlocutor, it is probably not out of place to try to illustrate what I meant by several quotes from the work of like-minded public intellectuals and researchers.

Public sociologist's fears. Since the notion of public sociology has already been invoked in this context, let us start with the already classical text on the topic written by the former American Sociological Association and current International Sociological Association president, Michael Burawoy. In his call for more public sociology, he warns that "increasingly, governments around the balo biti jasno da nisam ja iznio sve te argumente, baš kao što je Hanafi a ne ja pridonio retorički slikovit izraz dileme $\mathrm{s}$ kojom su suočeni akademski sociolozi na arapskom Istoku (»objavi globalno i nestani lokalno« ili pak »objavi lokalno i nestani globalno«).

Neznanje ne opravdava. Očigledna neobaviještenost o sadržaju i postavkama brojnih i dobro obaviještenih priloga širokoj međunarodnoj raspravi - od kojih neki sadrže i empirijske podatke izričito bibliometrijske naravi - ne opravdava mog sugovornika $u$ tome što odbacuje kao nerelevantnu moju zabrinutost mogućim iznevjeravanjem vlastite istraživačke misije i zaobilaženjem potreba lokalne zajednice pri pokušajima zadovoljavanja kriterija uspješnosti u sve globaliziranijem znanstvenom sustavu.

Ondje gdje on svodi ovu zabrinutost na »neutemeljen[u] bojaz[an] prema objavljivanju u međunarodnim časopisima« (Baćak, 2011: 241), iskusniji i obavješteniji sudionici u gorespomenutoj raspravi nude obilje argumenata i primjera koji proturječe takvom stavu. Budući da moje argumentativne sposobnosti očito nisu bile dovoljne da ovo razjasne mom sugovorniku, vjerojatno nije neprimjereno pokušati ilustrirati ono što sam želio reći s nekoliko navoda iz radova javnih intelektualaca $\mathrm{i}$ istraživača čije mišljenje dijelim.

Bojazni javnoga sociologa. S obzirom na to da je u ovom tekstu već spominjan pojam javne sociologije, možemo započeti s već klasičnim tekstom na tu temu koji je napisao bivši predsjednik Američkoga sociološkog društva (ASA) i sadašnji predsjednik Međunarodnoga sociološkog društva (ISA) Michael Burawoy. U svom pozivu na više javne sociologije, on upozorava da »sve više, 
world are holding their own academics, sociologists included, accountable to 'international' standards, which means publishing in 'Western' journals, and in particular American journals. It's happening in South Africa and Taiwan but also in countries with considerable resources, such as Norway. Driven by connections to the West and publishing in English, national sociologies lose their engagement with national problems and local issues" (Burawoy, 2005: 21).

Needless to say, such a warning - formulated by an extremely well-informed First World sociologist - predates by several years not only my "unfounded fears", but also Hanafi's description of the "publishing and perishing" mechanism I have reported on in my text. From this quote we can see that the mentioned problem of "loss of engagement with national problems and local issues" also affects "countries with considerable resources". In this context, it does not seem to me so unreasonable to be preoccupied with the potential bypassing of the needs of the local community in the inevitable and imminent move of the entire Croatian research system to a more globalized research context.

Policy advisor's fears. When it comes to my allegedly "unfounded fear" that "especially [...] young researchers, seeking recognition in an increasingly competitive context" could be tempted to "betray the demands of [their] own academic specialization" and be led to "act in tune with the priorities set before them by others, in order to be published and to be quoted" (Petrić, 2011: 111), it is probably best to quote firstly a general warning with an authoritative institutional background. vlade diljem svijeta smatraju svoje akademske djelatnike, što uključuje i sociologe, odgovornima 'međunarodnim' standardima, što znači objavljivanje $u$ časopisima na 'Zapadu', i to osobito u američkim časopisima. To se događa $u$ Južnoj Africi i na Tajvanu, ali također i u zemljama sa znatnim resursima, poput Norveške. Usmjeravajući se prema Zapadu i objavljivanju na engleskom, nacionalne sociologije sve se manje bave nacionalnim problemima i lokalnim temama« (Burawoy, 2005: 21).

Nije potrebno posebno naglašavati da ovo upozorenje - koje je izrekao iznimno dobro obaviješten sociolog iz Prvog svijeta - prethodi nekoliko godina ne samo mojim »neutemeljenim bojaznima«, nego i Hanafijevom opisu mehanizma »objavljivanja i nestajanja« o kojemu sam izvijestio u svom tekstu. Iz toga navoda možemo spoznati da »sve manje bav[ljenje] nacionalnim problemima i lokalnim temama« pogađa i »zemlj[e] sa znatnim resursima«. U tom kontekstu, ne čini mi se tako nerazumnim biti zabrinut zbog mogućeg zaobilaženja potreba lokalne zajednice pri neizbježnom i neposredno predstojećem pomaku cjelokupnog hrvatskog znanstvenog sustava prema globaliziranijem znanstvenom kontekstu.

Bojazan savjetnika javnih politi$k a$. Kad je pak riječ o mojoj navodno »neutemeljenoj bojazni« da bi »osobito mlad[i] [znanstvenici], željn[i] afirmacije u kompetitivnom okruženju « mogli biti $\mathrm{u}$ iskušenju »iznevjeriti zahtjeve vlastite akademske specijalizacije« i usmjeriti se »na istraživanja u skladu s prioritetima mogućnosti objave i postizanja citatnog odjeka« (Petrić, 2011: 111), vjerojatno je najbolje najprije navesti općenito upozorenje $\mathrm{s}$ autoritativnom institucionalnom pozadinom. 
In the recent report to the French Minister of Higher Education and Research on how to use bibliometrics properly to evaluate individual researchers, the French Academy of Sciences warns explicitly that "the importance of bibliometrics in some disciplines may encourage researchers to adapt their publications and even their work to the journal in which they wish to publish their articles rather than engaging in original and creative research" (Académie des sciences, 2011: 2). In the Recommendations section, this warning is expanded by the fear - according to my interlocutor "unfounded" - of the potential researchers' failure to "[persist] with a thematic continuity, at least for several years" (Académie des sciences, 2011: 5).

Scientometrist's description of the problem. In contrast with these remarks of a general nature, a research team of scientometrists based at the University of Granada has listed a number of concrete signs of the "illness" they claim is affecting a large number of researchers in Spain. Among the signs of this "illness" they choose to call "impactitis" are: "choosing the target journal on the basis of the impact factor alone without considering which audience is most appropriate for their work, hypertrophic self-citing, joining invisible citation colleges intended to increase the impact of their publications, and deliberately omitting to cite their scientific rivals or enemies". On the other hand, the "[i]nfected [local] editors, determined to see their journal indexed in Thomson Scientific's databases, sink to manipulating editorial policies in order to increase the journal's repercussion both among scholars and in the mass media" (Delgado López-Cózar, Ruiz-Pérez and Jiménez-Contreras, 2007).
U nedavnom izvješću francuskom ministru visokog obrazovanja i znanosti o tome kako ispravno koristiti bibliometriju pri evaluaciji pojedinačnih istraživača/ica, francuska Akademija znanosti eksplicite upozorava da »važnost bibliometrije u nekim disciplinama može potaknuti znanstvenike/ce da prilagode svoje publikacije i čak svoje djelovanje časopisu u kojemu žele objaviti članke umjesto da se poduhvate izvornih i kreativnih znanstvenih istraživanja« (Académie des sciences, 2011: 2). U dijelu s preporukama, ovo je upozorenje prošireno bojazni - prema mojem sugovorniku »neutemeljenom« - od mogućeg neuspjeha znanstvenika/ca da »ustraju u tematskom kontinuitetu, makar nekoliko godina« (Académie des sciences, 2011: 5).

Scientometrijski opis problema. Za razliku od ovih napomena opće prirode, znanstveno-istraživački tim scientometara sa Sveučilišta u Granadi naveo je više konkretnih znakova »bolesti« za koju tvrde da pogađa velik broj znanstvenika/ca u Španjolskoj. Među znacima ove »bolesti«, koju su odlučili nazvati »impactitis«, jesu: »odabir časopisa u kojem se želi objaviti isključivo na temelju čimbenika utjecaja bez razmatranja o tome koja bi publika bila najprimjerenija radu, hipertrofirano samocitiranje, uključivanje u nevidljive skupine osoba koje citiraju da bi se povećao citatni odjek vlastitih publiciranih radova, te namjerno necitiranje znanstvenih suparnika ili neprijatelja«. S druge strane, »[z]araženi [lokalni] urednici/e, odlučni postići da im se časopisi referiraju u bazama podataka Thomson Scientific, spali su na to da manipuliraju uredničkom politikom ne bi li povećali značaj časopisa i među znanstvenicima/ama i u masovnim medijima« (Delgado López-Cózar, RuizPérez i Jiménez-Contreras, 2007). 
What is also interesting in the quoted report is this team's assessment of the wider consequences of what my interlocutor refers to as "unfounded fears". According to the authors, the national system for evaluating researchers' productivity, introduced in 1989 and based on bibliometric criteria, ${ }^{5}$ has had rather devastating consequences on some levels.

On the one hand - the authors inform us - " $[\mathrm{t}]$ he increase in the number of Spanish source items in the Thomson Scientific databases since [the new] policy came into effect has been spectacular" (Delgado López-Cózar, Ruiz-Pérez and Jiménez-Contreras, 2007). Spanish science has been internationalized, the quality of articles has been significantly improved and the country has been incorporated into mainstream international research.

On the other hand - as the authors put it - "the impact factor has become the number that is devouring Spanish science". One negative effect has been "the destruction of Spanish as a language of science", which came about as a result

\footnotetext{
${ }^{5}$ The authors quote the Spanish parliamentary record that introduced the new determining factor in the government's evaluation of a researcher's output as saying that the basis for evaluation and funding will be "those articles of scientific worth in journals of recognized prestige, which shall be accepted to mean those that occupy relevant positions in the lists for science fields in the Subject Category Listings of the Journal Citation Reports of the Science Citation Index (Institute for Scientific Information (ISI), Philadelphia, PA, USA)" (Delgado López-Cózar, Ruiz-Pérez and Jiménez-Contreras, 2007). The stated aim of the new reward system was to improve the quality and the international visibility of Spanish science.
}

U navedenom izvješću zanimljiva je i procjena ovog znanstvenog tima o širim posljedicama onoga što moj sugovornik naziva »neutemeljenom bojazni«. Prema autorima, nacionalni sustav vrednovanja znanstvene produktivnosti, uveden 1989. i zasnovan na bibliometrijskim kriterijima, ${ }^{5}$ na nekim je razinama imao razorne posljedice.

$\mathrm{S}$ jedne strane - izvješćuju nas autori - »povećanje broja jedinica španjolskih izvora u bazama podataka Thomson Scientific od vremena kad je [nova] politika stupila na snagu bilo je spektakularno« (Delgado López-Cózar, RuizPérez i Jiménez-Contreras, 2007). Španjolska se znanost internacionalizirala, kvaliteta članaka znatno je unaprjeđena, a zemlja se uključila u maticu međunarodne znanstvene djelatnosti.

S druge strane - kao što to kažu autori - »čimbenik utjecaja postao je broj koji proždire španjolsku znanost«. Jedan od negativnih učinaka je »uništenje španjolskog kao jezika znanosti«, do kojega je došlo uslijed migracije najboljih članaka u strane časopise i posljedičnog

${ }^{5}$ Autori navode bilješku španjolskog parlamenta kojom je uveden novi presudni čimbenik u vladinom vrednovanju znanstvene produkcije pojedinačnih istraživača/ica, a koja kaže da će osnova vrednovanja i financiranja biti »oni članci znanstvene vrijednosti u časopisima s prepoznatim ugledom, što bi trebalo shvatiti da se odnosi na one koji zauzimaju relevantna mjesta na popisima znanstvenih polja u Subject Category Listings of the Journal Citation Reports of the Science Citation Index (Institute for Scientific Information (ISI), Philadelphia, PA, USA)« (Delgado López-Cózar, RuizPérez i Jiménez-Contreras, 2007). Kao svrha novog sustava nagrađivanja bilo je navedeno unaprjeđivanje kvalitete i međunarodne vidljivosti španjolske znanosti. 
of the migration of the best articles to foreign journals and the accompanying increasing neglect of Spanish journals. Another one is quite similar to the implied consequences of one of my "unfounded fears": according to the quoted authors, "[m]any research groups [in Spain] have altered their research agendas", the consequence of which has been that "research with potential practical applications, and research on topics that are local, regional and national in scope, has been replaced by basic research in topics more likely to be better received by the international research community" (Delgado López-Cózar, Ruiz-Pérez and Jiménez-Contreras, 2007).

Hegemonic accumulation or civil society? In many ways, the picture of the negative consequences of "internationalization" of research based on bibliometric criteria presented above, reminds one of the perceived negative consequences for the sustainability of local economies brought about by heeding the advice and guidance of so-called "international financial institutions".

Introducing an article on the banks analyzed as "sites of knowledge production", the current editor of the journal European Societies, Göran Therborn, has indeed noted "striking similarities with the current vogue of quantified evaluation of academic research" in the "quantification of risk assessment and its replacement of qualitative evaluation of clients" (Therborn, 2011: 505).

But what is more interesting in specifically sociological terms is the general conclusion of the article in question. Its authors set out to "reconsider the Giddens predictions about the growing permeability of society and institutions to sociological insights and narratives of the self zanemarivanja španjolskih časopisa. Drugi je negativni učinak prilično sličan impliciranim posljedicama nekih od mojih »neutemeljenih bojazni«: prema navedenim autorima, $»[\mathrm{~m}]$ noge su znanstveno-istraživačke skupine [u Španjolskoj] izmijenile svoje istraživačke agende«, a posljedica toga je da su »znanstvena istraživanja $s$ potencijalno praktičnim primjenama, te znanstvena istraživanja o temama čiji je raspon lokalan, regionalan i nacionalan, zamijenjena fundamentalnim istraživanjima o temama koje imaju veću vjerojatnost biti dobro primljene $\mathrm{u}$ međunarodnoj znanstvenoj zajednici« (Delgado López-Cózar, Ruiz-Pérez i Jiménez-Contreras, 2007).

Hegemonijska akumulacija ili civilno društvo? Predočena slika negativnih posljedica »internacionalizacije« znanosti zasnovane na bibliometrijskim kriterijima umnogome podsjeća na percipirane negativne posljedice po održivost lokalnih ekonomija koje nastupaju uslijed uvažavanja savjeta i vodstva takozvanih »međunarodnih financijskih ustanova «.

Uvodeći članak o bankama analiziranim kao »mjestima proizvodnje znanja«, aktualni urednik časopisa European Societies Göran Therborn, doista je primijetio »zapanjujuće sličnosti s aktualnom modom kvantificiranih evaluacija znanstvenog istraživanja«, kad je riječ o »kvantifikaciji procjene rizika $\mathrm{i}$ tome da ona sve više zamjenjuje kvalitativne evaluacije klijenata« (Therborn, 2011: 505).

No, u specifično sociološkom smislu, još je zanimljiviji opći zaključak članka o kojemu je riječ. Njegovi autori željeli su "ponovo razmotriti Giddensove prognoze o sve većoj propusnosti društva i institucija prema sociološkim spoznajama i pripovijestima o sebi u 
in late modernity" (Lopes and Marques, 2011: 510). Following their empirical research, carried out in Portugal, on "how some patterns of behaviour, collective aspirations, regional economic trends, and other matters of a certain sociological nature are used by credit institutions” (Lopes and Marques, 2011: 510), they have realized that actually "we may be taking one step forwards in the comprehension of economics as the actual pandiscourse of advanced societies" (Lopes and Marques, 2011: 511).

The authors are aware of the fact that economics is also a social science, although - as they point out - it has tended to distance itself from other social science disciplines by emphasizing econometric and statistical approaches. This has made it seem closer to the scientific paradigms of the natural sciences, but it has unfortunately also reduced its social science qualities. Indeed, Lopes and Marques (2011: 510) claim that "when adapted or translated into economic terms, many classic sociological concepts become a caricature of what their mentors and followers intended them to be and easily comply with the hegemonic principle of accumulation”.

The question is: do we want this for sociology as well? Would we want sociological interpretations of the social world to become "isomorphous" with the current trends in this respect, too, in other words to melt into the already proposed "positivist fantasy" of a "new unified social science" that "all too easily dissolves reflexivity, that is, the critical and public moments of social science" (Burawoy, 2005: 22)? And if economics - already overrepresented in the discourse dominant in "advanced societies" - would be a logical hegemon of this new sci- kasnoj modernosti« (Lopes i Marques, 2011: 510). Nakon empirijskog istraživanja obavljenog u Portugalu, o tome »kako kreditne ustanove koriste neke obrasce ponašanja, kolektivne težnje, regionalne ekonomske trendove te druge teme stanovite sociološke naravi« (Lopes i Marques, 2011: 510), došli su, međutim, do spoznaje da su zapravo »možda korak bliže razumijevanju ekonomske znanosti kao aktualnog pandiskursa naprednih društava« (Lopes i Marques, 2011: 511).

Autori su svjesni da je i ekonomija društvena znanost, premda - kako ističu - pokazuje tendenciju distanciranja od drugih disciplina društvenih znanosti naglašavanjem ekonometrijskih i statističkih pristupa. Zbog ovoga se čini bližom paradigmama prirodnih znanosti, ali je to nažalost istodobno smanjilo njezine kvalitete kao društvene znanosti. I doista, Lopes i Marques (2011: 510) tvrde da $»$ kad se prilagode ili prevedu u ekonomske termine, mnogi klasični sociološki koncepti postaju karikature onoga što su njihovi mentori i sljedbenici htjeli da budu i lako se slažu s hegemonijskim načelom akumulacije«.

Pitanje je: želimo li ovo i sociologiji? Bismo li željeli da sociološke interpretacije društvenog svijeta i u ovom pogledu postanu »izomorfne« s aktualnim trendovima, drugim riječima da se rastope u već predloženu »pozitivističku fantaziju« »nove unificirane društvene znanosti« koja »prelako rastapa refleksivnost, to jest, kritičke i javne momente društvene znanosti« (Burawoy, 2005: 22)? A ako bi ekonomija - ionako nadzastupljena u diskursu koji prevladava $\mathrm{u}$ »naprednim društvima« - bila logični hegemon ove nove znanosti, koja bi disciplina ostala za proučavanje »drža- 
ence, which discipline would be left to study "the state or the economy from the standpoint of civil society", as Burawoy (2005: 24) argues sociology does and should do?

Toward a reflexive internationalization. In my view, the concept of sociology in the public service - obviously related to Burawoy's vision and TomićKoludrović's version of it - corresponds much better to the current needs of both Croatian sociology and Croatian society than any sort of narrowly professionally defined concern, such as that expressed by the wish to achieve visibility in international journal production. ${ }^{6}$

In spite of what my interlocutor obviously thinks, this does not mean that I am "against" internationalization or for that matter - "against" publishing in foreign journals. This only means that I advocate the concept of internationalization that would be reflexive - so to speak - from within and without, and not necessarily motivated by misplaced bibliometric criteria, a mere wish to achieve and maintain "international visibility", or a response to legislative measures of the national (or supranational) research funding authorities.

\footnotetext{
${ }^{6}$ When reading a statement like this, one should of course be aware that Burawoy's vision of public sociology does not perceive "professional sociology" as an enemy of policy and public sociology but as the "sine qua non of their existence - providing both legitimacy and expertise" (Burawoy, 2005: 10). In other words, my support of sociology in the public service by no means excludes the need for the further development of professional sociology in Croatia. However, in my view, intra-professional discussions should also always include what Burawoy (2005: 11) calls "a dialogue about ends”.
}

ve ili ekonomije sa stajališta civilnog društva«, kao što Burawoy (2005: 24) tvrdi da sociologija čini i da bi trebala činiti?

Prema refleksivnoj internacionalizaciji. Po mom mišljenju, pojam sociologije u službi javnosti - očito srodan Burawoyevoj viziji i njezinoj verziji u Tomić-Koludrović - znatno bolje odgovara aktualnim potrebama i hrvatske sociologije i hrvatskog društva nego bilo koja usko profesionalno definirana tema, kao što je to izražena želja za postizanjem vidljivosti u međunarodnoj časopisnoj produkciji. ${ }^{6}$

Usprkos tome što moj sugovornik očito misli drukčije, to ne znači da sam »protiv« internacionalizacije ili - kad je o tome riječ - "protiv« objavljivanja u stranim časopisima. To samo znači da zagovaram pojam internacionalizacije koja bi bila refleksivna - takoreći - i iznutra $\mathrm{i}$ izvana, te ne nužno motivirana pogrešno primijenjenim bibliometrijskim kriterijima, pukom željom da se postigne i održi »međunarodna vidljivost«, ili pak da se odgovori na zakonske mjere nacionalnih (ili nadnacionalnih) tijela koja financiraju znanstvena istraživanja.

${ }^{6} \mathrm{Kad}$ se pročita tvrdnja poput ove, valja naravno biti svjestan da Burawoyeva vizija javne sociologije ne shvaća »profesionalnu sociologiju« kao neprijatelja sociologije javnih politika ili javne sociologije, nego kao »sine qua non njihova postojanja - koji osigurava legitimnost i stručnost« (Burawoy, 2005: 10). Drugim riječima, moja potpora sociologiji u službi javnosti nipošto ne isključuje daljnji razvoj profesionalne sociologije u Hrvatskoj. Međutim, po mom mišljenju, unutarstrukovne rasprave također bi uvijek trebale uključivati ono što Burawoy (2005: 11) naziva »dijalogom o krajnjim ciljevima«. 
I consider it indispensable that the research community participates in and reflects on the issues similar to the one my interlocutor and I are currently discussing, and that it does so in the public service and not primarily in the service of the narrowly conceived professional promotion of its members. This can perhaps sound too idealistic, but - as I have stated in my previous Forum contribution - "I actually see a better international future for Croatian sociology only if 'internationalization' also [italics added] happens in situ" (Petrić, 2011: 112).

This does not necessarily make me a "nationalist", not even a "methodological” one. Rather, I would argue that the interplay between the "local" and "international" concerns implied by the statement above is shaped by and contributes to a good "supranationalist" cause. In the case of Croatia, I see it as contributing - among other things - to the further unfolding of the positive sides of European unification. $^{7}$

Points of agreement and disagreement. Finally, in spite of my interlocutor's incredulity, I would like to repeat what I have already stated in my previous contribution: "I agree with [the] basic diagnosis (Croatian sociologists publish

\footnotetext{
${ }^{7}$ In my previous Forum contribution, I have suggested several measures that I thought were conducive to an "internationalization" "from within" of the social science journal scene in Croatia. This time, I would like to hint at the possibilities opening up in the European Higher Education Area in terms of launching international joint degree programs, as well as joint research projects, conferences and workshops. All of these require the upgrading of research capacity comparable to that achieved by preparing research articles for publication in demanding international journals.
}

Smatram nužnim da zajednica znanstvenih istraživača/ica sudjeluje i razmišlja o temama poput ove o kojoj moj sugovornik i ja sada raspravljamo, kao i da čini to u službi javnosti a ne prvenstveno u službi usko shvaćene profesionalne promocije svojih članova/ica. Ovo možda može zvučati odviše idealistički, ali - kao što sam ustvrdio u svom prethodnom prilogu u Forumu - »bolju međunarodnu budućnost hrvatske sociologije vidim zapravo samo ako se 'internacionalizacija' dogodi $i$ [kurziv dodan] in situ« (Petrić, 2011: 112).

Ovo me ne čini nužno »nacionalistom«, pa čak ni samo »metodološkim nacionalistom«. Prije bih ustvrdio da međuigra između »lokalnih« i »međunarodnih« tema kakvu implicira gore citirana tvrdnja pridonosi dobroj »nadnacionalnoj« svrsi. U slučaju Hrvatske, vidim je kao nešto što - između ostaloga - pridonosi daljnjem otkrivanju pozitivnih strana europskih integracija. $^{7}$

Slaganja $i$ neslaganja. Konačno, usprkos nevjerici moga sugovornika, želio bih ponoviti ono što sam već ustvrdio u svom prethodnom prilogu: »Slažem se s [...] temeljnom dijagnozom (hrvatski sociolozi/ginje nedovolj-

${ }^{7} \mathrm{U}$ svom prethodnom prilogu u Forumu, predložio sam nekoliko mjera za koje mislim da vode »internacionalizaciji« »iznutra« scene društvenih časopisa u Hrvatskoj. Ovaj put, volio bih spomenuti neke od mogućnosti koje se otvaraju u Europskom prostoru visokog obrazovanja, u smislu pokretanja združenih studijskih programa, kao i zajedničkih istraživačkih projekata, konferencija i radionica. Sve to traži poboljšanje znanstveno-istraživačke sposobnosti usporedivo $\mathrm{s}$ onim koje se postiže pripremom znanstvenih članaka za objavljivanje u zahtjevnim međunarodnim časopisima. 
insufficiently in international journals)" put forth in the Štulhofer, Baćak and Šuljok (2010) Forum contribution, "as well as with the suggested therapy (there should be incentives for outstanding research achievements, more rigorous criteria of academic career advancement, and changes in the system of education of junior researchers)" (Petrić, 2011: 99$100)$. Where we disagree is obviously in the understanding of the forms the proposed therapy should take and in the exact meaning of each of its components. ${ }^{8}$

However, in the case of my interlocutor's conclusion that - "[a]fter we have recognized $[\ldots]$ that our international productivity is scarce, the next step should be [...] to examine the potential reasons behind parochialism" (Baćak, 2011: 244), I cannot say anything other than that I wholeheartedly agree. I am only warning in advance that, in that analysis, bibliometric methods will not be of much help.

\footnotetext{
${ }^{8}$ It is clear that my interlocutor and other members of the team that prepared the bibliometric analysis setting this discussion in motion pay a lot of attention to this form of a researcher's evaluation. A rigorous and informed peer-review evaluation, including international experts with appropriate expertise, would seem to me to be a preferable solution. Likewise, the understanding of what constitutes an "outstanding research achievement" as well as what form should a changed system of education of junior researchers take, would probably not be the same.
}

no objavljuju u međunarodnim publikacijama)« koju su Štulhofer, Baćak i Šuljok (2010) iznijeli u svom prilogu u Forumu, »kao i s predloženom terapijom (nagrađivanje iznimnih znanstvenih postignuća, uvođenje zahtjevnijih uvjeta akademskog napredovanja te promjene u načinu poduke znanstvenog podmlatka)« (Petrić, 2011: 99-100). Očito je pak da se ne slažemo u tome kakve bi oblike predložena terapija trebala poprimiti i što je točno značenje svake od njezinih komponenti. ${ }^{8}$

Međutim, kad je riječ o zaključku mog sugovornika da bi $-»[$ n]akon što smo ustvrdili $[\ldots]$ da nismo dovoljno međunarodno produktivni, sljedeći [...] korak trebao biti [...] osvrnuti se na potencijalne razloge za provincijalnost « (Baćak, 2011: 244), ne mogu reći ništa drugo nego da se bezrezervno slažem. Jedino unaprijed upozoravam da $\mathrm{u}$ toj analizi bibliometrijske metode neće biti od previše pomoći.

${ }^{8}$ Jasno je da moj sugovornik i drugi članovi tima koji je pripremio bibliometrijsku analizu koja je pokrenula našu raspravu, polažu prilično pozornosti ovom obliku evaluacije znanstvenika. Rigorozna i obaviještena evaluacija kolega/ica, koja bi uključila i adekvatno kvalificirane međunarodne stručnjake, meni bi se činila rješenjem kojem valja dati prednost. $\mathrm{Na}$ isti način, razumijevanje toga što čini »iznimno znanstveno postignuće « vjerojatno ne bi bilo isto, kao ni mišljenje o tome kakve bi točno promjene valjalo unijeti u sustav poduke znanstvenog podmlatka. 


\section{LITERATURA / REFERENCES}

Académie des sciences (2011). »On the Proper Use of Bibliometrics to Evaluate Individual Researchers: Report Presented on 17 January 2011 to the Minister of Higher Education and Research«, Institut de France, Académie des sciences, http://www. academie-sciences.fr/activite/rapport/ avis170111gb.pdf (19. 12. 2011).

Baćak, Valerio (2011). »Bauk internacionalizacije u hrvatskoj sociologiji / The Spectre of Internationalization in Croatian Sociology«, Revija za sociologiju, 41 (2): 239-245. doi:10.5613/rzs.41.2.5

Burawoy, Michael (2005) »2004 Presidential Address: For Public Sociology«, American Sociological Review, 70 (1): 4-28.

Delgado López-Cózar, Emilio, RuizPérez, Rafael \& Jiménez-Contreras, Evaristo (2007). »Impact of the impact factor in Spain«, British Medical Journal [Recent Rapid Responses - Fri, 2007-04-20 15:58], http:// www.bmj.com/content/334/7593/561 ?tab=responses (19. 12. 2011).

Fleck, Christian (2010). »Diversity or Fragmentation in Europe's Sociology: Lessons to be Learned?«, in: Michael Burawoy, Mau-kuei Chang \& Michelle Fei-yu Hsieh (eds). Facing an Unequal World: Challenges for a Global Sociology (Volume 3: Europe and Concluding Reflections). Taipei: Institute of Sociology, Academia Sinica, Council of National Associations of the International Sociological Association, 3-22, http://www.ios.sinica.edu.tw/cna/ download/proceedings/38.Fleck.Austria.pdf (19. 12. 2011).

Hanafi, Sari (2010). »Publish Globally and Perish Locally: Rating System in the Elite Universities in the Arab East«, ASA Footnotes, 38 (5): 5-6, http://www.asanet.org/footnotes/ mayjun10/images_new/MayJun10 Footnotes.pdf (19. 12. 2011).

Hanafi, Sari (2011). »University Systems in the Arab East: Publish Globally and Perish Locally vs Publish Locally and Perish Globally«, Current Sociology, 59 (3): 291-309. doi: $10.1177 / 0011392111400782$

HEFCE (2010). »Bibliometrics pilot exercise 2009«, Higher Education Funding Council for England, http:// www.hefce.ac.uk/research/ref/biblio (19. 12. 2011).

Jacobs, Jerry A. (2011). »Journal Rankings in Sociology: Using the $\mathrm{H}$ Index with Google Scholar«, Population Studies Center, University of Pennsylvania, PSC Working Paper Series, PSC 11-05, http://repository. upenn.edu/psc_working_papers/29.

Lopes, Daniel Seabra \& Marques, Rafael (2011). »How Credit Institutions Look at Society: Economics, Sociology, and the Problem of Social Reflexivity Reconsidered «, European Societies, 13 (4): 509-533. doi:10.1 080/14616696.2011.580856

Petrić, Mirko (2011). »Bibliometrija cum grano / Bibliometrics cum grano«, Revija za sociologiju, 41 (1): 99-114. doi:10.5613/rzs.41.1.6

Štulhofer, Aleksandar, Baćak, Valerio \& Šuljok, Adrijana (2010). »Provincijalni karakter hrvatske sociologije? / A Parochial Status of Croatian Sociology?«, Revija za sociologiju, 40 (1): 103-108.

Therborn, Göran (2011). »Editorial«, European Societies, 13 (4): 505-507. doi:10.1080/14616696.2011.607919

Tomić-Koludrović, Inga (2009). »Pogled u budućnost: sociologija kao multi- 
paradigmatska, refleksivna i javna znanost / A View of the Future: Sociology as a Multiparadigmatic, Reflexive and Public Science«, Revija za sociologiju, 40[39] (3-4): 139-181.

Van Raan, Anthony F. J. (2005). »Fatal Attraction: Conceptual and Methodological Problems in the Ranking of Universities by Bibliometric Met- hods«, Scientometrics, 62 (1): $133-$ 143. doi:10.1007/s11192-005-0008-6 Wimmer, Andreas \& Glick Schiller, Nina (2002). »Methodological Nationalism and Beyond: Nation-state Building, Migration and the Social Sciences«, Global Networks, 2 (4): 301-334. doi:10.1111/1471-0374. 00043 